\title{
PV POWER PLANTS SITES SELECTION USING GIS-FAHP BASED APPROACH IN NORTH-WESTERN MOROCCO.
}

\author{
Meryem Sedrati ${ }^{\mathrm{a}, *}$, Mehdi Maanan ${ }^{\mathrm{a}}$, Hassan Rhinane $^{\mathrm{a}}$ \\ ${ }^{a}$ Earth Sciences Department, Faculty of Sciences Ain Chock, University Hassan II, Casablanca, Morocco.
}

Commission IV

KEY WORDS: Fuzzy Analytic Hierarchy Process, Geographic information system, Multi-Criterion Decision Analysis, Solar photovoltaic power plants, Renewable energy, Photovoltaic potential, Installation capacity, Northwestern Morocco.

\begin{abstract}
:
Energy plays a crucial role in the economy of any country. One of the most recent trends in global development is the transition to "green" growth. Morocco is keeping pace with its growth by promising to increase renewable energy capacity to $42 \%$ of total installed capacity by 2020 and to $52 \%$ by 2030 . This study develops a framework that aims to determine the optimal areas for deploying photovoltaic (PV) installation in two stages. The first stage aims at excluding the undesirable areas such as forests, rivers and agricultural land. The second stage consists in defining the suitability of sites based on seven criteria; solar irradiation, land surface temperature, slopes, slope orientation, distance from power lines, distance from main roads, distance of urban area. In this study we are using fuzzy logic and fuzzy membership functions in order to create criteria layers in the environment of Geographic Information System (GIS) that allowing the integration of a Multi-Criterion Decision Analysis (MCDA) to identify the best sites to deploy PV solar power plants in north-western Morocco. Also, the Analytic Hierarchy Process (AHP) technique is used to determine weights for each one of the criteria. Results obtained from the spatial approach shows that the major portion of the studied area was judged inappropriate for solar farms installations. Also, it shows that only $5.11 \%$ (8500 Ha) of the territory demonstrate high suitability for PV solar installations located in the southern part of our studied area with a potential of electricity generation, from the areas with high suitability level, assuming a PV system efficiency of $6.48 \%$; equivalent to $5.39 \mathrm{Twh} / \mathrm{year}$ with an installed capacity of $4.02 \mathrm{GW}$ and an annual carbon emission reduction of $3697.54 \mathrm{Kt}-\mathrm{CO} 2 / \mathrm{year}$. The resulting suitability map can be used as a decision support tool to help the public policy makers to integrate green energy into their policies.
\end{abstract}

\section{INTRODUCTION}

Energy is the center of almost every real challenge confronting the present world according to the United Nations Development Program (UNDP), which becomes effective in January 2016, as a major aspect of the 17 Sustainable Development Goals (SDGs) to be accomplished by 2030 (Gielen et al., 2019). Many studies highlighted the importance of energy such as (Asakereh et al., 2017) and (Singh et al., 2002) as a key feature for economic growth and social development. Energy also plays a major role allowing access to competitive and sustainable resources (Le and Nguyen, 2019). Truth be told, energy utilization concerning each person is one of the major records to assess society's improvement in terms of economical and social aspect (Mart1 and Ebenhack, 2008; Steinberger and Roberts, 2010; Santika et al., 2019). The worldwide economy depends mainly on fossil energy bearers, such as, coal, oil, and petroleum gas (Mostafaeipour et al., 2011; Noor et al., 2018; Liu et al., 2019). Despite the fact that the common reservations of petroleum products are constrained (Asakereh et al., 2017) and it is presumed to be exhausted during the following century if their utilization is proceeded by the present degree (Uyan, 2013). Additionally, the endless utilization of non-renewable energy source is, therefore, harming the world's environment ( $\tilde{A}, 2006$; Shao and Chu, 2008).

Energy demand is increasing rapidly as the world population and economic grow; especially in developing countries (Touili et al., 2018). Thus, existing energy resources cannot satisfy the ever growing demand (Dincer and Acar, 2014). It is expected that by 2050 , interest for energy might be multiplied or even significantly increased (Royston et al., 2018). Therefore, it is extremely fundamental to achieve perfect, inexhaustible, manageable and ecologically agreeable alternative energy assets (Mirhosseini et al., 2011). Among various sustainable power reservoirs, solar energy, primarily photovoltaic (PV), has turned into a significant factor in the all-inclusive power generation (Buker et al., 2015; Azmi et al., 2017; Bye et al., 2018; GarcíaÁlvarez et al., 2018; Allouhi et al., 2019). The International Energy Agency (IEA) predicts that power production from PV will contribute $20 \%$ of the generally speaking and renewable power by 2050 (Komendantova et al., 2012; Merrouni et al., 2014).

Morocco has both high capability and high potential of sustainable and renewable power sources that cannot only cover part of country needs but also export the surplus to its neighbors (Boie et al., 2016; Alami Merrouni et al., 2018a; Benasla et al., 2019). That is the reason why in 2008, Moroccan authorities have initiated a National Renewable Energy and Efficiency Strategy (Tsikalakis et al., 2011; Tahri et al., 2015) to advance energy proficiency in order to achieve $42 \%$ (14\% Solar, $14 \%$ wind, $14 \%$ Hydraulic) by 2020 and $52 \%$ by 2030 (20\% Solar, $20 \%$ wind, $12 \%$ Hydraulic) target of environmentally friendly power energy generation (Attari et al., 2016). The Moroccan Agency for Solar Energy (MASEN) was created in parallel in order to carry the MSP's objective of realization, and it set a goal to manufacture five solar plants spread on the homeland (Alami Merrouni et al., 2018a; Allouhi et al., 2019). The MSP started with the introduction of the initial segment of the Noor Complex in Ouarzazate toward the start of 2016 (Cantoni and Rignall, 2019). With a limit of $160 \mathrm{MWe}$ and 3.5 hours of capacity, this plant is considered the largest on the planet. The second and the third part of Noor Complex are under development (Alami Merrouni et al., 2018b). The installation of the two outstanding pieces of the Noor Complex is anticipated to be accomplished in the few next years, and the overall capability of the Noor Complex will achieve 500 MWe (Touili et al., 2018).

During the last ten years, numerous research has been carried out in the field of solar energy. The researches were mainly focused on site selection and available energy potential at those sites (Arán Carrión et al., 2008; Charabi and Gastli, 2011; 
Asakereh et al., 2014, 2017; Al Garni and Awasthi, 2017; Azmi et al., 2017; Hafeznia et al., 2017; Alami Merrouni et al., 2018b; Giamalaki and Tsoutsos, 2019; Yang et al., 2019), and Geographic Information Systems (GIS) has a significant role in carrying out those researches, therefore, consistently been used to select different sites for solar energy plantation (Arnette and Zobel, 2011). Moreover, GIS in conjunction with Multi-Criteria Decision Analysis (MCDA) methods is used to evaluate spatial criteria qualitatively and quantitatively.

On the other hand, the Analytic Hierarchy Process (AHP) is a powerful tool making possible the handling of MCDM. AHP is a decision-aided method consisting in decomposing complex problems having multiple factors into a hierarchical structure, and each level is aggregation of specific elements (Dağdeviren et al., 2008; Kaya and Kahraman, 2010). In real-world implementation some problems' decision data could be assessed while other cannot. Consequently, Fuzzy AHP is an extension of classic AHP method that considers the fuzziness of the decision makers.

The FAHP approach was proposed by (Chang, 1996) as a manner to solve the limitations of AHP (Charabi and Gastli, 2011; Shaw et al., 2012; Tian and Yan, 2013; Asakereh et al., 2017; Hafeznia et al., 2017). Even though its high process complexity, FAHP is more efficient than the conventional AHP especially when dealing with problems of place selection in order to install a PV plant.

In this article, AHP technique was used to settle the weighting of each criterion. Fuzzy logic and fuzzy membership functions were used to construct layers of criteria in the Geographic Information System (GIS) environment allowing the integration of multi-criteria decision making (MCDM) in order to distinguish the best sites for the establishment of solar photovoltaic plants in the north-western part of Morocco precisely in Tangier-Assilah prefecture and Fahs anjra. To the best of our knowledge, this is the first study based on fuzzy logic for the exploration of optimal locations to install solar photovoltaic plants in Morocco. Aforementioned is the novelty concerning this article

The rest of this paper is organized as follows, in section 2 we present the study area, in section 3 we propose the methodology, Section 4 is dedicated to results and discussion and finally we conclude the paper in section 5 .

\section{STUDY AREA}

The study area is located in northwestern side of Morocco as illustrated in (Fig. 1), it covers an area of $1662 \mathrm{~km}^{2}$ with a population of 1136964 (HCP, September, 2014). The study area includes Tangier-Assilah prefecture and Fahs Anjra province. The longitudinal geographical expanses are $5^{\circ}$ $23^{\prime} 10^{\prime \prime} \mathrm{W}$ and $6^{\circ} 00^{\prime} 49^{\prime \prime} \mathrm{W}$, the latitudinal stretches are $35^{\circ}$ $54^{\prime} 29^{\prime \prime} \mathrm{N}$ and $35^{\circ} 20^{\prime} 08^{\prime \prime} \mathrm{N}$.

The area where the study was conducted has sub-humid climate where annual average precipitation is $700 \mathrm{~mm}$. Rainfall is mainly during winter season and dry season spans from May to October. In the study area annual solar radiation means were between 460 to $1557 \mathrm{KWh} / \mathrm{m}^{2}$.

\section{MATERIALS AND METHODS}

The aim of this work is the potential assessment of utility scale PV solar energy through many stages described in (Fig. 1). Our proposed methodology is explained in several stages as presented in the flow chart of figure 1 . The first step is to define and gather all data layers needed and judged to be useful in our case for the analysis in order to set up the digital geo-database.
Next, we establish the constraint factors that will determine how much an area is unsuitable as a binary map, where " 0 " refers to unsuitable areas and "1" to suitable areas . The next step is to determine the weights of the evaluation criteria according the AHP algorithm. The parameters were evaluated by experts based on a set of pair-wise comparison. After calculating factor weights for each level, it is required to set up priority values in the new approach combining fuzzy logic. Finally, based on output of previous steps, we predict, (i) energy generation potential, (ii) installation capacity and (iii) $\mathrm{CO} 2$ emission. The methodology flowchart summarizes the main techniques used.

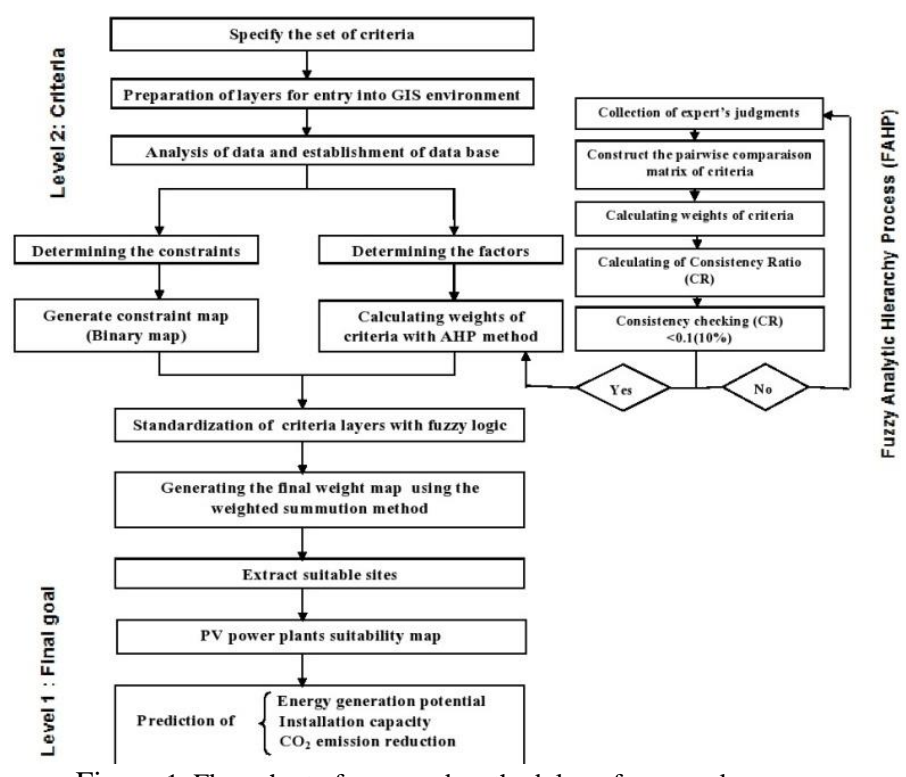

Figure 1. Flow chart of proposed methodology framework.

\subsection{Criteria selection}

The selection of the most suitable sites for the installation of PV solar power plants is very complex and different parameters must be taken under consideration during the analysis. The criteria identified in this study were divided into five main groups: climatic, geographical, technical, socio-economic and environmental.

The evaluation criteria were chosen based on the expected results and a review of literature concerning similarly case studies on specifically PV renewable energies. Each criteria utilized in this study are described below, and the details of these criteria is given in (Table 1).

\subsubsection{Climatic criteria:}

Solar Irradiation $\left(\boldsymbol{K W h} / \mathbf{m}^{2}\right)$ : Solar energy is simply the energy produced by radiation of sun. From all over the globe, solar radiation is one of the best sources of renewable energy according to (Baños et al., 2011). The solar radiation was extracted from Digital Elevation Model (DEM) by applying spatial analysis; represented by the area solar radiation in GIS software tools (Clifton and Boruff, 2010; Charabi and Gastli, 2011; Sun et al., 2013; Merrouni et al., 2014; Watson and Hudson, 2015; Sadeghi and Karimi, 2017). Based on the results of primary estimation, annual solar irradiation on 2018 range from 460 to $1557 \mathrm{Kwh} / \mathrm{m}^{2}$.

Retrieval of Land Surface Temperature (LST): Satellite images are an important source of data to obtain information on the surface of the earth without direct contact with it. 
In this study, we used four thermals bands of Landsat 8 downloaded from("USGS") to retrieve LST ( Madanian et al., 2018).

\subsubsection{Geographical criteria:}

Slope and slope orientation: The DEM was used to extract

\subsubsection{Socio-economic criteria:}

Urban area: All urban areas located at a distance of less than $1000 \mathrm{~m}$ are not suitable to implement a solar power plant project due to several significant adverse impacts of the project on the environment or human health.

\subsection{Constraint areas}

Areas of constraint include forests, rivers and agricultural lands. A constraint layer has been created containing places where it is

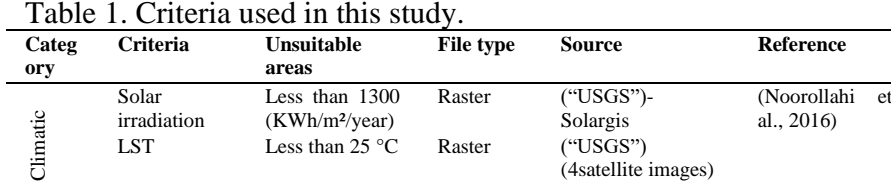

\begin{tabular}{|c|c|c|c|c|}
\hline Slope & $\begin{array}{l}\text { Slope more } \\
\text { than } 10 \%\end{array}$ & Raster & (“USGS") & $\begin{array}{l}\text { (Hafeznia et al., } \\
\text { 2017) }\end{array}$ \\
\hline Aspect & - & Raster & (“USGS") & $\begin{array}{l}\text { (Georgiou and } \\
\text { Skarlatos, } \\
2016 \text { ) }\end{array}$ \\
\hline
\end{tabular}
unauthorized to install solar farms or which, as far as possible have harmful effects on human life or the environment, have been excluded to be chosen as suitable sites as a solar farm. The use of boolean logic in a GIS environment has made it possible to eliminate areas that are judged inappropriate for the installation of PV plants. In accordance with boolean logic, the potential areas get the value 1 while the others get the value 0 . The choice of constraint values in (Table 1) was based on the values available in the literature and was approved by experts in previous works (Georgiou and Skarlatos, 2016; Hafeznia et al., 2017).

\begin{tabular}{|c|c|c|c|c|c|c|}
\hline & $\begin{array}{l}\text { Road } \\
\text { network }\end{array}$ & Less than & & Vecteur & (“OSM”) & (Hafeznia et al., \\
\hline 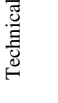 & Power lines & $\begin{array}{l}\text { More than } \\
\mathrm{m}\end{array}$ & 500 & Vecteur & $\begin{array}{l}\text { Developpement } \\
\text { plan of the } \\
\text { prefecture Tangier } \\
\text { Assillah }\end{array}$ & $\begin{array}{l}\text { (Sabo et al., } \\
2016)\end{array}$ \\
\hline 兽 & Urban area & $\begin{array}{l}\text { Less than } 1 \\
\mathrm{~m}\end{array}$ & 1000 & Vecteur & $\begin{array}{l}\text { Developpement } \\
\text { plan of the } \\
\text { prefecture Tangier } \\
\text { Assillah }\end{array}$ & $\begin{array}{l}\text { (Asakereh } \\
\text { al., 2017) }\end{array}$ \\
\hline \multirow{3}{*}{ 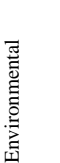 } & $\begin{array}{l}\text { Agricultural } \\
\text { lands }\end{array}$ & $\begin{array}{l}\text { Less than } \\
\mathrm{m}\end{array}$ & 100 & Vecteur & (“OSM") & \multirow{3}{*}{$\begin{array}{l}\text { (Hafeznia et al., } \\
2017 \text { ) } \\
\text { (Georgiou and } \\
\text { Skarlatos, } \\
2016 \text { ) } \\
\text { (Hafeznia et al., }\end{array}$} \\
\hline & Forest & $\begin{array}{l}\text { Less than } \\
\mathrm{m}\end{array}$ & 200 & Vecteur & (“OSM") & \\
\hline & River & Less than & 200 & Vecteur & (“OSM") & \\
\hline
\end{tabular}

\subsection{GIS and multi-criteria decision Analysis (MCDA-GIS)}

Fuzzy Analytic Hierarchy Process (FAHP): In order to achieve the spatial planning objective of a PV installation, it is necessary to separate the appropriate areas from inappropriate ones, then evaluating these areas using a mathematical model. In this study, the FAHP model was applied to determine the weights of each criterion in the context of a multicriteria decision model.

The construction of fuzzy evaluation matrices consists in performing a pairwise comparison. This comparison is based on the reasoning and weighting of the criteria presented in similar previous studies; concerning the suitability of solar sites having similar characteristics as our studied area (Charabi and Gastli, 2011; Georgiou and Skarlatos, 2016). Equation (8) express the pairwise comparison matrix model (Saaty, 2007).

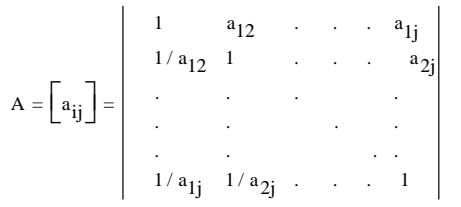

Source:Comparison matrix of Thomas SAATY(1984)

The result of the pairwise comparison is a matrix where each element value ranges from 1 to 9 (Sánchez-Lozano et al., 2016). The elements of the diagonal of the matrix are always equal to 1 while the nondiagonal elements indicate the relative perception of the importance of one characteristic with respect to another. After obtaining the comparison matrix, the weight vectors $\mathrm{W}=$ (w1, w2, ..., wn) were determined using eigenvector method proposed in (Saaty, 1990), then the weighting process consists of normalizing the pairwise comparison matrix $\mathrm{A}=$ (aij) using Equation (9) (Lin and Tang, 2003) and then calculating the weighting criteria using Equation (10) (Lin and Tang, 2003).

$$
\mathrm{a}_{\mathrm{ij}}=\frac{\mathrm{a}_{\mathrm{ij}}}{\Sigma^{\mathrm{n}}{ }_{\mathrm{i}=1} \mathrm{a}_{\mathrm{ij}}} \quad \text { (9) } \mathrm{W}_{\mathrm{i}}=\frac{\Sigma^{\mathrm{n}}{ }_{\mathrm{i}=1} \mathrm{a}_{\mathrm{ij}}}{\mathrm{N}}
$$

For the acceptance of the weighting results, it is essential to have the means to measure the consistency of the judgments issued. In most cases, a greater value of consistency in judgments implies better judgments; this implies that the estimates of the weights relative to the criteria adopted are all the more reliable.

The coherence index expressed by the mathematical formula of equation (11) measures the reliability of the comparison expressed in coherent judgments. The greater the consistency 
index becomes, the more inconsistent the judgments expressed in the comparison matrix and vice versa.

$$
\mathrm{CI}=\frac{(\lambda \max -\mathrm{N})}{(\mathrm{N}-1)}
$$

With $\mathrm{N}$ : is the number of elements compared.

$\lambda \max ,:$ a value calculated on the basis of the average of the SAATY matrix values of the eigenvectors.

Moreover, the experiment established by (Saaty, 1990) allows to define the Coherence Ratio (CR) as the ratio of the coherence index calculated on the matrix corresponding to the judgments of the actors and the Random Index (RI) of a matrix of the same dimension. The coherence ratio calculated by the mathematical formula below (12) measures the logical coherence of the judgments of the experts. It makes it possible to evaluate the coherence of the judgments by the method of comparison in pairs.

$$
\mathrm{CR}=\frac{\mathrm{CI}}{\mathrm{RI}}
$$

Where RI: is the random index based on the number of criteria listed in Table 2.

According to SAATY, if CR is greater than 0.1 , there is an inconsistency in comparing pairs and then, the matrix resulting from the comparisons will have to be re-evaluated. The pairwise comparison of the criteria applied for our case study, as well as the calculations relating to the different parameters gave the following results: $\lambda \max =28.624, \mathrm{CI}=0.03604, \mathrm{RI}=1.32, \mathrm{CR}$ $=0.027<0.1$. The coherence ratio is less than 0.1 , which means that the criteria judgments have been consistent.

Having finished with calculating the weights for each criterion, the next step consists in implementing these priority values in the new fuzzy logic approach. As a sample, fuzzy modeling of spatial data contains the following steps:

Standardization of criteria: After preparation, it is important to have standardized maps, moreover the values in various inputs maps may have various meaning and could contain many measurement units (e.g.percentage of slope

map,temperature,etc.) It is mandatory to unify the values so as to make them reciprocally comparable by turning them into comparable measurement units $(0-1)$, in other words making the values unscalable.

Membership in a set is not dichotomous in the hypothesis of fuzzy logic (i.e. in or out); membership instead has degrees ranging between 0 and 1 that is to say fuzzy set has a characteristic of fuzzy membership grade from 0 to 1 to indicate increasement in a continuous way from nonmembership to complete membership according to (Zadeh, 1965). It is important to define a membership function for all the criteria in order to calculate the degree of membership for every pixel. In this study, linear and trapezoidal membership functions are used. The details of the criteria of fuzzy model are listed in (Table 4).

\begin{tabular}{|c|c|c|c|c|c|}
\hline \multirow[t]{2}{*}{ Criteria } & \multirow{2}{*}{$\begin{array}{l}\text { Fuzzy } \\
\text { membership } \\
\text { function }\end{array}$} & \multicolumn{4}{|c|}{ Function parameters } \\
\hline & & $\mathbf{A}$ & B & $\mathbf{C}$ & D \\
\hline $\begin{array}{l}\text { Solar } \\
\text { Irradiation }\end{array}$ & $\begin{array}{l}\text { Linear- } \\
\text { ascending }\end{array}$ & $\begin{array}{l}1300(\mathrm{KWh} / \\
\left.\mathrm{m}^{2} / \mathrm{y}\right)\end{array}$ & $\begin{array}{l}1557(\mathrm{KWh} / \\
\left.\mathrm{m}^{2} / \mathrm{y}\right)\end{array}$ & - & - \\
\hline LST & $\begin{array}{l}\text { Linear- } \\
\text { ascending }\end{array}$ & $25^{\circ} \mathrm{C}$ & $34^{\circ} \mathrm{C}$ & - & - \\
\hline Slope & $\begin{array}{l}\text { Linear- } \\
\text { descending }\end{array}$ & - & - & $3 \%$ & $10 \%$ \\
\hline $\begin{array}{l}\text { Electricity } \\
\text { network }\end{array}$ & $\begin{array}{l}\text { Linear- } \\
\text { descending }\end{array}$ & - & - & $\begin{array}{l}250 \\
\mathrm{~m}\end{array}$ & $\begin{array}{l}500 \\
\mathrm{~m}\end{array}$ \\
\hline $\begin{array}{l}\text { Road } \\
\text { network }\end{array}$ & Trapezoidal & $300 \mathrm{~m}$ & $500 \mathrm{~m}$ & $\begin{array}{l}1000 \\
\mathrm{~m}\end{array}$ & $\begin{array}{l}6000 \\
m\end{array}$ \\
\hline $\begin{array}{l}\text { Urban } \\
\text { area }\end{array}$ & $\begin{array}{l}\text { Linear- } \\
\text { ascending }\end{array}$ & $1000 \mathrm{~m}$ & $5000 \mathrm{~m}$ & - & - \\
\hline
\end{tabular}

Table 4. Criteria used in the fuzzy model of this study.
Aggregation of criteria: For each criteria, we calculate the final intensity based on fuzzy overlay of weight of each parameter (w) already defined using AHP and fuzzy information layers following eq.(13) described as follows:

$$
\sum_{\mathrm{i}=1}^{\mathrm{n}} \mathrm{W}_{\mathrm{i}} * \mathrm{X}_{\mathrm{i}}(\mathrm{x})
$$

where $\mathrm{n}$ is the number of factors, $\mathrm{W}_{\mathrm{i}}$ is the weight of the factor $\mathrm{i}$, and $X_{i}$ is the degree of membership for the factor i. because the values of both the weight and the degree of membership are between 0 and 1 , the value of the index is also between 0 and 1 , where a value of 0 represents the (totally unsuitable) and 1 indicates the (100\% appropriate).

\subsection{Solar energy potential}

Energy plays a fundamental function in improving the way of life of the population, just as in the economic intensity of any nation.

The calculation of solar energy production is an important step in the evaluation of feasibility. As a general rule, the estimated operation time of a station is between 25 and 30 years.

The electricity generation potential is calculated using equation (14) proposed in (Charabi and Gastli, 2011; Kawase et al., 2013; Sabo et al., 2016; Asakereh et al., 2017) :

$$
\mathrm{GP}=\mathrm{SR} * \mathrm{CA} * \mathrm{AF} * \eta_{\mathrm{Tot}} \quad(14)
$$

$\mathrm{GP}$ :Yearly potential of solar energy produced in (KWh/year).

$\mathrm{SR}$ :Yearly solar radiation $\left(\mathrm{KWh} / \mathrm{m}^{2} /\right.$ year $)$.

CA :Photovoltaic field surface $\left(\mathrm{m}^{2}\right)$.

$\mathrm{AF}$ : Area factor.

$\eta$ :efficiency panel.

The AF term is the land mass that can be covered by solar panels. The AF value is determined by using the maximum coverage of the solar panel with the minimum shading effect. It find out to be $75 \%$ and $70 \%$ respectively for similar researches carried out before (Arnette and Zobel, 2011; Charabi and Gastli, 2011).

\subsection{Estimation of installation capacity}

Two parameters are used to calculate the installation capacity (IC): annual electricity generation potentiel (EGP) and annual solar irradiation (ASR) using the following equation (16):

$$
\text { IC }=\text { EGP } / \text { ASR }
$$

\subsection{Reduction of $\mathrm{CO} 2$ emissions}

We calculate the $\mathrm{CO} 2$ emission reduction potential from the generation potential obtained in Section III.5. To estimate the annual carbon emissions from the PV system we use the following equation (17):

$$
\mathrm{ER} \mathrm{co} 2=\mathrm{RF} \operatorname{co} 2 * \mathrm{EG}
$$

Where RF co2 is emission reduction factor; $\mathrm{CO} 2$ emissions per $\mathrm{kWh}$ for electricity generated by fuels in Morocco is about $717.7742 \mathrm{~g} / \mathrm{kWh}$ (IEA, 2011) and EG is the annual electricity generation.

\section{RESULTS AND DISCUSSIONS}

In this study, land suitability for locating potential sites has been evaluated by FAHP, and GIS. Seven factors, including climatic, and geographical, were selected and their rank of the membership function was calculated using fuzzy sets. (Table 6) below summarizes the estimation of each one of the criteria according to AHP method guidelines. It is also comparing the weight of each criterion pair-wisely. The selection of each criterion is based on previous studies similar to our field of focus. Therefore, the final weights of the corresponding criteria show that solar irradiation has the highest weight $(31 \%)$ since 
it is the most important criterion, followed by land surface temperature. The slope and aspect criteria represent respectively $14 \%$ and $11 \%$ of the criteria weights. According to the literature, the proximity of urban areas is the least important factor, as the proximity of existing power lines and roads is more economical.

Table 6. Pair-wise comparison matrix of criteria and estimated weights.

\begin{tabular}{|c|c|c|c|c|c|c|c|}
\hline & $\begin{array}{l}\text { Solar } \\
\text { irradiation }\end{array}$ & LST & Slope & Aspect & $\begin{array}{l}\text { Power } \\
\text { lines }\end{array}$ & Roads & $\begin{array}{l}\text { Urban } \\
\text { areas }\end{array}$ \\
\hline $\begin{array}{l}\text { Solar } \\
\text { irradiation }\end{array}$ & 1 & 2 & 5 & 3 & 3 & 3 & 4 \\
\hline LST & $1 / 2$ & 1 & 3 & 5 & 3 & 3 & 5 \\
\hline Slope & $1 / 5$ & $1 / 3$ & 1 & 2 & 2 & 3 & 4 \\
\hline Aspect & $1 / 3$ & $1 / 5$ & $1 / 2$ & 1 & 2 & 2 & 3 \\
\hline $\begin{array}{l}\text { Power } \\
\text { lines }\end{array}$ & $1 / 3$ & $1 / 3$ & $1 / 2$ & $1 / 2$ & 1 & 1 & 2 \\
\hline Roads & $1 / 3$ & $1 / 3$ & $1 / 3$ & $1 / 2$ & 1 & 1 & 2 \\
\hline $\begin{array}{l}\text { Urban } \\
\text { areas }\end{array}$ & $1 / 4$ & $1 / 5$ & $1 / 4$ & $1 / 3$ & $1 / 2$ & $1 / 2$ & 1 \\
\hline
\end{tabular}

\section{$C R=0.027$}

In figure 3 below we illustrate the fuzzy membership layers of criteria which consists in 7 criterias, scaling from 0 to 1 , indicating the better location to implant PV facilities. Each map pixel has a corresponding value from 0 to 1 in fuzzy logic, where 1 represents absolute certainty of membership and 0 for non-members. The intensity factor gets high whenever the membership value increases.

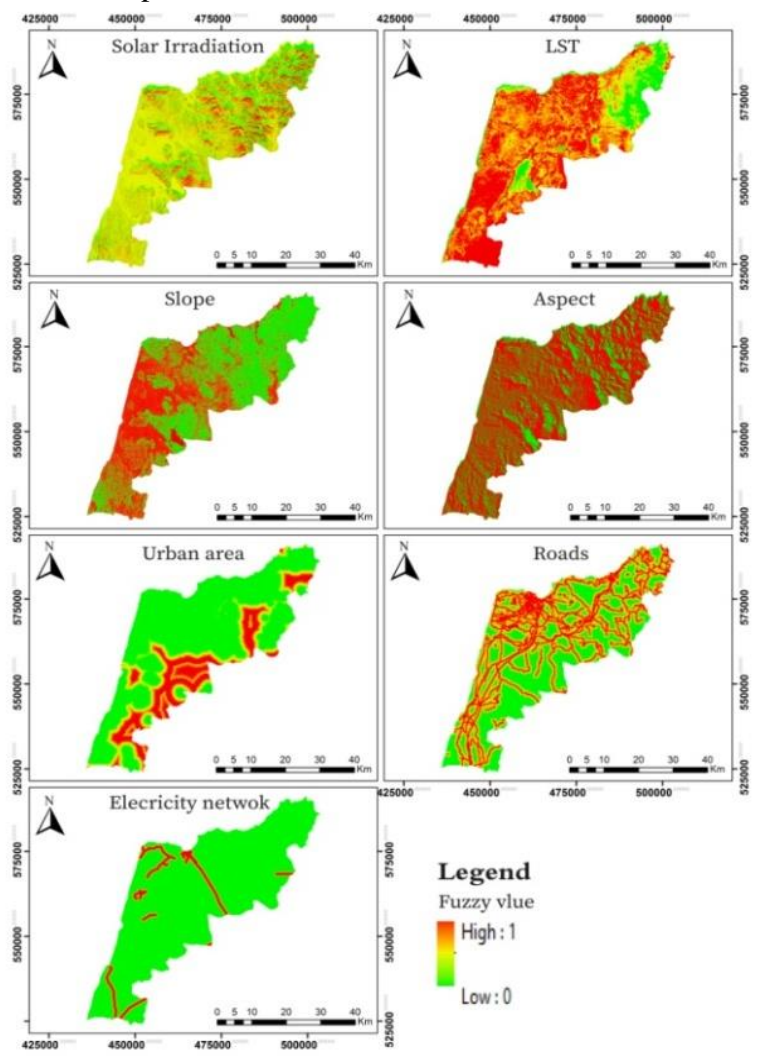

Figure 3. Produced maps by fuzzy model

Ultimately, the land suitability to implement PV using FAHP method is represented by the final layer in the (Fig. 4) The variation of fuzzy values (varying from 0 to 1 ) is reflected by changing the color of map which represent non-exploitable locations and best locations to implant solar farms. In addition, we determine four suitability levels based on the fuzzy membership values concerning locations; (i) unsuitable, (ii) low, (iii) medium and (iv) high.

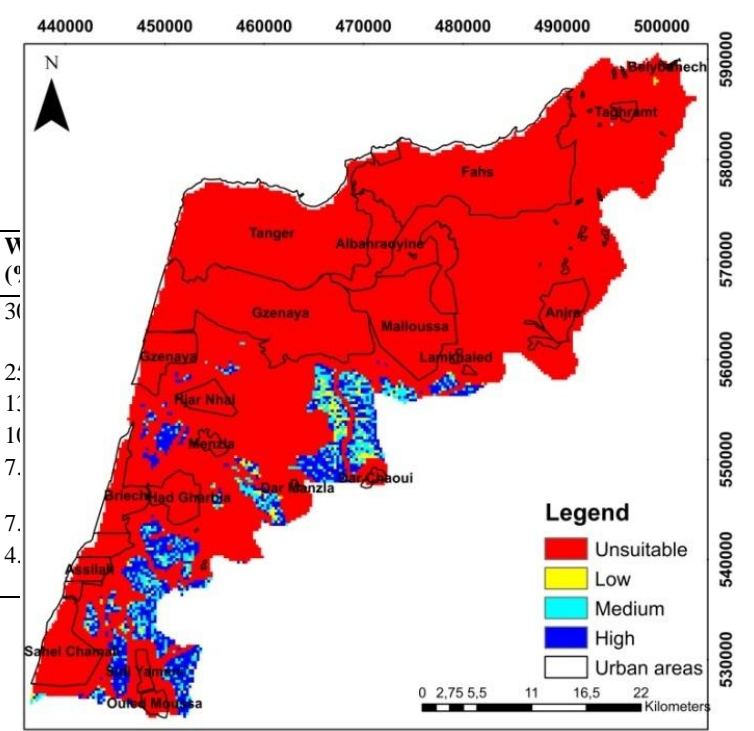

Figure 4. Land suitability for PV power plants.

In a preliminary process, we eliminated all the unsuitable areas, obviously, $90.82 \%\left(1509 \mathrm{~km}^{2}\right)$ of the studied area with the fuzzy value of zero is non exploitable. On the other hand, $5.11 \%$ $\left(85 \mathrm{~km}^{2}\right)$ is completely exploitable with the fuzzy value of one. What is left of the area of study has fuzzy value between zero and one as illustrated in (Table 7). Consequently, the most exploitable areas are located in flat land, precisely in the south of Hjar nhal, north dar Manzla, south Had Gharbia, East Assilah, East Sahel Chamali, North of Sidi Lyamani, and East Oulad Moussa.

Table 7. The area and approximate share of each level of land suitability in the study area.

\begin{tabular}{lll}
\hline Land suitability & Area $\left(\mathbf{K m}^{2}\right)$ & Share of case study(\%) \\
& & \\
\hline High & 84.87 & 5.11 \\
Medium & 52.52 & 3.16 \\
Low & 15.28 & 0.92 \\
Unsuitable & 1509.48 & 90.82 \\
Total & 1662.15 & 100 \\
\hline
\end{tabular}

Steep terrains, forested zones in the mountainous areas, agricultural land and rivers in the plains of the study area cause the greatest constraints to deploy solar power plants. In fact, about $46.48 \%$ of the land in this region have a slope with than $10 \%$ which makes it unsuitable to deploy solar farms and its fuzzy membership value took the value zero. Also, land having a slope with $3 \%$ or less is completely suitable for solar farm implantation and its value on fuzzy membership was considered to be one. From all the studied area, only $12.15 \%$ have the value 1 of its fuzzy membership. Only $41.37 \%$ of the territory has a slope between 3 and $10 \%$. About $19.5 \%$ and $45 \%$ of the total of the study area is either forestry areas or agricultural lands ("Regional Directorate of Water and Forests and the fight against Rif Desertification," 2018).

(Table 8) represents the solar electricity generation potential using PV with various efficiencies in different classes.

Electricity generation potential from areas with high suitability level, have $6.48 \%$ for PV system efficiency reaching up to 5.39TWh/year. This amount represents $17.26 \%$ of the total net electricity produced nationwide in 2015. Total annual net 
electricity production in Morocco was 31.22TWh in 2015 according to International Energy Agency.

The electricity's annual consumption according to ("World Bank") in Morocco is around $789.43 \mathrm{kWh}$ per inhabitant as reported in 2017. In order to determine the number of users to use electricity from PV system, we devide the produced energy by the electricity comsumption per capita as follows:

$$
\text { Number of person }=\frac{\mathrm{PV}_{\text {output }}}{\mathrm{C}_{\mathrm{a}}}
$$

Where Number of person: the number of people benefiting from the energy produced and $\mathrm{Ca}$ represents the annual electricity consumption per capita in Morocco. The (Table 9) above summarizes the calculation in

function of the used PV module.

The results obtained in (Table 9) above show that the production could cover the electricity needs of about 6827711 inhabitants in the case of using a PV module with $10 \%$ of panel efficiency, while 10247900 inhabitants in case of $15 \%$ of panel efficiency is used and 13604752 inhabitants using 20\% of panel efficiency. In other words, the produced energy could cover up to 6 times the needs of the area's inhabitants.

Based on the equation on the equation (16) mentioned in section 3.5 the capacity of installation is about $4.02 \mathrm{GW}$. The amount of total carbon emission reduction is estimated to be $3697 \mathrm{kt}$ $\mathrm{CO} 2 /$ Year in our study area by using equation (17) already mentioned in section 3.6.

Table8. Solar electricity potential by using PV system with different module efficiencies in different levels.

\begin{tabular}{llllll}
\hline Class name & & Unsuitable & Low & Moderate & $\begin{array}{l}\text { High } \\
\text { suitable }\end{array}$ \\
\hline Area(Percent) & & 91 & 1 & 3 & 5 \\
Electricity & $\mathbf{A}^{\mathbf{a}}$ & 94.72 & 0.94 & 3.29 & 5.39 \\
Generation & $\mathbf{B}^{\mathrm{b}}$ & 142.08 & 1.41 & 4.94 & 8.09 \\
Potential(Twh/year) & $\mathbf{C}^{\mathrm{c}}$ & 188.57 & 1.88 & 6.55 & 10.74 \\
\hline
\end{tabular}

Table9. Number of inhabitants could benefit from PV production using different module efficiencies in high suitable area.

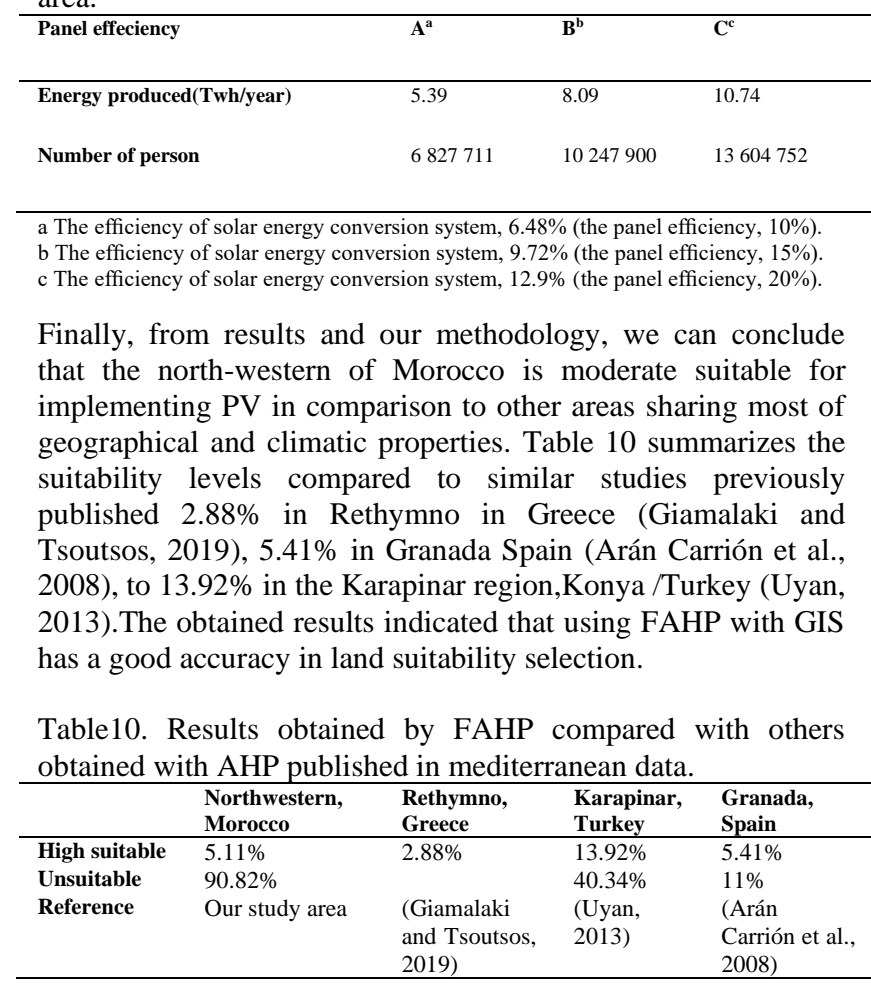

\section{CONCLUSION}

The map of PV power plants suitability was realized through the GIS-based FAHP method. Climatic criteria have significantly important in studying the suitability regarding the expert's judgements and the literature. In this study, we choose seven criteria, namely solar irradiation, land surface temperature, slope, aspect, proximity to power lines, proximity to roads, and distance of urban areas were used in the geographical, climatic, socio-economic, and technical evaluation. In order to prepare the constraint map we used constraint criteria (i.e., environmental) such as forests, rivers and water bodies, and agricultural lands. The inconsistencies in the linguistic judgements were insignificant $(=\mathrm{CR} 0.027<10 \%)$, also the obtained weights reveal that solar irradiation has a highest influence on the sitting of solar farm in the study area with a weight is equal to 0.31.In this study we integrate the fuzzy sets and AHP methods with GIS which provides a powerful and accurate combination for the analysis of land suitability for solar power plants. The results of the resultants map clearly reveal that only a small portion of the study area have high suitability level for hosting PV power plants and $90.82 \%$ of the total study area are not suitable. Southern parts of the study area are viable for PV power plants. The south of Hjar nhal, north dar Manzla, south Had Gharbia, East Assilah, East Sahel Chamali, North of Sidi Lyamani, and East Oulad moussa were found to possess several excellent sites for solar farm development. All the lands in Northern region of study area are unsuitable for sitting solar farm. Annual electricity production related to the high suitable area with conversion efficiency of $10 \%$ is roughly equivalent to $5.39 \mathrm{TWh}$ which represent $17.26 \%$ of the total net electricity produced nationwide in 2015 and with a capacity of installation of about $4.02 \mathrm{GW}$. The future vision of the study is to use machine learning tools such as neural networks in order to predict the suitable areas based on primary data of these area.

\section{REFERENCES}

Ã, D.I.D., 2006, Silviculture and biology of short-rotation woody crops in temperate regions: Then and now: v. 30, p. 696-705, doi:10.1016/j.biombioe.2005.02.008.

Alami Merrouni, A., Elwali Elalaoui, F., Ghennioui, A., Mezrhab, A., and Mezrhab, A., 2018a, A GIS-AHP combination for the sites assessment of large-scale CSP plants with dry and wet cooling systems. Case study: Eastern Morocco: Solar Energy, v. 166, p. 2-12, doi:10.1016/j.solener.2018.03.038.

Alami Merrouni, A., Elwali Elalaoui, F., Mezrhab, A., Mezrhab, A., and Ghennioui, A., 2018b, Large scale PV sites selection by combining GIS and Analytical Hierarchy Process. Case study: Eastern Morocco: Renewable Energy, v. 119, p. 863-873, doi:10.1016/j.renene.2017.10.044.

Allouhi, A., Saadani, R., Buker, M.S., Kousksou, T., Jamil, A., and Rahmoune, M., 2019, Energetic, economic and environmental (3E) analyses and LCOE estimation of three technologies of PV grid-connected systems under different climates: Solar Energy, v. 178, p. 25-36, doi:10.1016/j.solener.2018.11.060.

Arán Carrión, J., Espín Estrella, A., Aznar Dols, F., Zamorano Toro, M., Rodríguez, M., and Ramos Ridao, A., 2008, Environmental decision-support systems for evaluating the carrying capacity of land areas: Optimal site selection for grid-connected photovoltaic power plants: Renewable and Sustainable Energy Reviews, v. 12, p. 2358-2380, doi:10.1016/j.rser.2007.06.011.

Arnette, A.N., and Zobel, C.W., 2011, Spatial analysis of renewable energy potential in the greater southern Appalachian mountains: Renewable Energy, v. 36, p. 2785-2798, doi:10.1016/j.renene.2011.04.024.

Asakereh, A., Omid, M., Alimardani, R., and Sarmadian, F., 2014, Developing a GIS-based Fuzzy AHP Model for Selecting Solar Energy Sites in Shodirwan Region in Iran: International Journal 
of Advanced Science and Technology, v. 68, p. 37-48, doi:10.14257/ijast.2014.68.04.

Asakereh, A., Soleymani, M., and Sheikhdavoodi, M.J., 2017, A GISbased Fuzzy-AHP method for the evaluation of solar farms locations: Case study in Khuzestan province, Iran: Solar Energy, v. 155, p. 342-353, doi:10.1016/j.solener.2017.05.075

Attari, K., Elyaakoubi, A., and Asselman, A., 2016, Performance analysis and investigation of a grid-connected photovoltaic installation in Morocco: Energy Reports, v. 2, p. 261-266, doi:10.1016/j.egyr.2016.10.004

Azmi, R., Kacimi, I., and Amar, H., 2017, Photovoltaic Site Suitability Analysis using Analytical Hierarchy Process and Sensitivity Analysis Methods with GIS and Remote Sensing in Southern Morocco: v. 2.

Baños, R., Manzano-Agugliaro, F., Montoya, F.G., Gil, C., Alcayde, A., and Gómez, J., 2011, Optimization methods applied to renewable and sustainable energy: A review: Renewable and Sustainable Energy Reviews, v. 15, p. 1753-1766, doi:10.1016/j.rser.2010.12.008.

Benasla, M., Hess, D., Allaoui, T., Brahami, M., and Denaï, M., 2019 , The transition towards a sustainable energy system in Europe: What role can North Africa's solar resources play? Energy Strategy Reviews, v. 24, p. 1-13, doi:10.1016/j.esr.2019.01.007.

Boie, I., Kost, C., Bohn, S., Agsten, M., Bretschneider, P., Snigovyi, O., Pudlik, M., Ragwitz, M., Schlegl, T., and Westermann, D., 2016, Opportunities and challenges of high renewable energy deployment and electricity exchange for North Africa and Europe - Scenarios for power sector and transmission infrastructure in 2030 and 2050: Renewable Energy, v. 87, p. 130-144, doi:10.1016/j.renene.2015.10.008.

Buker, M.S., Mempouo, B., and Riffat, S.B., 2015, Experimental investigation of a building integrated photovoltaic/thermal roof collector combined with a liquid desiccant enhanced indirect evaporative cooling system: Energy Conversion and Management, v. $101, \quad$ p. 239-254, doi:10.1016/j.enconman.2015.05.026.

Bye, B., Fæhn, T., and Rosnes, O., 2018, Residential energy efficiency policies: Costs, emissions and rebound effects: Energy, v. 143 , p. 191-201, doi:10.1016/j.energy.2017.10.103.

Cantoni, R., and Rignall, K., 2019, Kingdom of the Sun: a critical, multiscalar analysis of Morocco's solar energy strategy: Energy Research and Social Science, v. 51, p. 20-31, doi:10.1016/j.erss.2018.12.012.

Carlson, T.N., and Ripley, D.A., 1997, On the relation between NDVI, fractional vegetation cover, and leaf area index: Remote Sensing of Environment, v. 62, p. 241-252, doi:10.1016/S00344257(97)00104-1

Chander, G., Markham, B.L., and Helder, D.L., 2009, Summary of current radiometric calibration coefficients for Landsat MSS, TM, ETM+, and EO-1 ALI sensors: Remote Sensing of Environment, v. 113, p. 893-903, doi:10.1016/j.rse.2009.01.007.

Chang, D.Y., 1996, Applications of the extent analysis method on fuzzy AHP: European Journal of Operational Research, v. 95, p. 649655, doi:10.1016/0377-2217(95)00300-2.

Charabi, Y., and Gastli, A., 2011, PV site suitability analysis using GISbased spatial fuzzy multi-criteria evaluation: Renewable Energy, v. 36, p. 2554-2561, doi:10.1016/j.renene.2010.10.037.

Clifton, J., and Boruff, B.J., 2010, Assessing the potential for concentrated solar power development in rural Australia: Energy Policy, v. 38, p. 5272-5280, doi:10.1016/j.enpol.2010.05.036.

Dağdeviren, M., Yüksel, I., and Kurt, M., 2008, A fuzzy analytic network process (ANP) model to identify faulty behavior risk (FBR) in work system: Safety Science, v. 46, p. 771-783, doi:10.1016/j.ssci.2007.02.002.

Dincer, I., and Acar, C., 2014, Review and evaluation of hydrogen production methods for better sustainability: International Journal of Hydrogen Energy, v. 40, p. 11094-11111, doi:10.1016/j.ijhydene.2014.12.035.

García-Álvarez, M.T., Cabeza-García, L., and Soares, I., 2018, Assessment of energy policies to promote photovoltaic generation in the European Union: Energy, v. 151, p. 864-874, doi:10.1016/j.energy.2018.03.066

Al Garni, H.Z., and Awasthi, A., 2017, A Fuzzy AHP and GIS-based approach to prioritize utility-scale solar PV sites in Saudi Arabia: 2017 IEEE International Conference on Systems, Man, and Cybernetics, SMC 2017, v. 2017-Janua, p. 1244-1249, doi:10.1109/SMC.2017.8122783.

Georgiou, A., and Skarlatos, D., 2016, Optimal site selection for sitting a solar park using multi-criteria decision analysis and geographical information systems: Geoscientific Instrumentation, Methods and Data Systems, v. 5, p. 321-332, doi:10.5194/gi-5-321-2016.

Giamalaki, M., and Tsoutsos, T., 2019, Sustainable siting of solar power installations in Mediterranean using a GIS/AHP approach: Renewable Energy, v. 141, p. 64-75, doi:10.1016/j.renene.2019.03.100.

Gielen, D., Boshell, F., Saygin, D., Bazilian, M.D., Wagner, N., and Gorini, R., 2019, The role of renewable energy in the global energy transformation: Energy Strategy Reviews, v. 24, p. 38 50, doi:10.1016/j.esr.2019.01.006.

De Griend \&Owe, V., 1993, International Journal of Remote Sensing Simulating the relationship between thermal emissivity and the Normalized Difference Vegetation Index: v. 16, p. 3211-3216.

Hafeznia, H., Yousefi, H., and Razi Astaraei, F., 2017, A novel framework for the potential assessment of utility-scale photovoltaic solar energy, application to eastern Iran: Energy Conversion and Management, v. 151, p. 240-258, doi:10.1016/j.enconman.2017.08.076.

http://projects.worldbank.org/P131256/?lang=en\&tab=details Projects : MA- Noor Ouarzazate Concentrated Solar Power Project|The World Bank: http://projects.worldbank.org/P131256/?lang=en\&tab=details (accessed June 2019)

http://www.masen.ma/fr/masen/, http://www.masen.ma/fr/ (accessed June 2019).

Jimenez-Munoz, J.C., Sobrino, J.A., Skokovic, D., Mattar, C., and Cristobal, J., 2014, Land surface temperature retrieval methods from landsat- 8 thermal infrared sensor data: IEEE Geoscience and Remote Sensing Letters, v. 11, p. 1840-1843, doi:10.1109/LGRS.2014.2312032

Kawase, M., Okajima, K., and Uchiyama, Y., 2013, Evaluation of Potential Geographic Distribution for Large-Scale Photovoltaic System in Suburbs of China: Journal of Renewable Energy, v. 2013, p. 1-8, doi:10.1155/2013/106063.

Kaya, T., and Kahraman, C., 2010, Multicriteria renewable energy planning using an integrated fuzzy VIKOR \& AHP methodology: The case of Istanbul: Energy, v. 35, p. 2517-2527, doi:10.1016/j.energy.2010.02.051

Komendantova, N., Patt, A., Barras, L., and Battaglini, A., 2012, Perception of risks in renewable energy projects: The case of concentrated solar power in North Africa: Energy Policy, v. 40, p. 103-109, doi:10.1016/j.enpol.2009.12.008.

Kubler, S., Robert, J., Derigent, W., Voisin, A., and Le Traon, Y., 2016 A state-of the-art survey \& testbed of fuzzy AHP (FAHP) applications: Expert Systems with Applications, v. 65, p. 398422, doi:10.1016/j.eswa.2016.08.064.

Laarhoven, V., and Pedrycz, W., 1983, Delft University: Fuzzy Sets and Systems, v. 11, p. 229-241.

Le, T.H., and Nguyen, C.P., 2019, Is energy security a driver for economic growth? Evidence from a global sample: Energy Policy, v. 129, p. 436-451, doi:10.1016/j.enpol.2019.02.038.

Lin, S.-C., and Tang, T.-Y., 2003, Factor assessment of the environmental impact for Tainan Technology Industrial Park in Taiwan: Ecosystems and Sustainable Development. Volume I., v. 63, p. 11-229, http://search.proquest.com/docview/16176126?accountid=8144 $\% 5$ Cnhttp://sfx.aub.aau.dk/sfxaub?url_ver=Z39.88-

2004\&rft_val_fmt=info:ofi/fmt:kev:mtx:book\&genre=conferenc e\&sid=ProQ:Pollution+Abstracts\&atitle $=\&$ title=Factor+assessm ent+of+the+environmental+impact+

Liu, Z., Yu, H., and Liu, R., 2019, ACCEPTED MANUSCRIPT A novel energy supply and demand matching model in park integrated energy system: Energy, doi:10.1016/j.energy.2019.04.049.

Madanian, M., Soffianian, A.R., Soltani Koupai, S., Pourmanafi, S., and Momeni, M., 2018, The study of thermal pattern changes using Landsat-derived land surface temperature in the central part of Isfahan province: Sustainable Cities and Society, v. 39, p. 650661, doi:10.1016/j.scs.2018.03.018. 
Martı, D.M., and Ebenhack, B.W., 2008, Understanding the role of energy consumption in human development through the use of saturation phenomena: v. 36 , p. 1430-1435, doi:10.1016/j.enpol.2007.12.016.

Merrouni, A.A., Mezrhab, A., and Mezrhab, A., 2014, CSP sites suitability analysis in the Eastern region of Morocco A.: Sustainable Energy Technologies and Assessments, v. 18, p. 615, doi:10.1016/j.seta.2016.09.006.

Mirhosseini, M., Sharifi, F., and Sedaghat, A., 2011, Assessing the wind energy potential locations in province of Semnan in Iran: Renewable and Sustainable Energy Reviews, v. 15, p. 449-459, doi:10.1016/j.rser.2010.09.029.

Mostafaeipour, A., Sedaghat, A., Dehghan-Niri, A.A., and Kalantar, V., 2011, Wind energy feasibility study for city of Shahrbabak in Iran: Renewable and Sustainable Energy Reviews, v. 15, p. 2545-2556, doi:10.1016/j.rser.2011.02.030.

Noor, S., Yang, W., Guo, M., Dam, K.H. Van, and Wang, X., 2018, Energy Demand Side Management within micro-grid networks enhanced by blockchain: Applied Energy, v. 228, p. 1385-1398, doi:10.1016/j.apenergy.2018.07.012.

Noorollahi, E., Fadai, D., Shirazi, M.A., and Ghodsipour, S.H., 2016 Land suitability analysis for solar farms exploitation using GIS and fuzzy analytic hierarchy process (FAHP) - A case study of Iran: Energies, v. 9, p. 1-24, doi:10.3390/en9080643.

OSM, https://www.openstreetmap.org/\#map=12/35.7306/-5.8832 (accessed June 2019)

Regional Directorate of Water and Forests and the fight against Rif Desertification, 2018, https://www.hcp.ma/regiontanger/attachment/1322593/ (accessed June 2019).

Royston, S., Selby, J., and Shove, E., 2018, Invisible energy policies : A new agenda for energy demand reduction: Energy Policy, v. 123, p. 127-135, doi:10.1016/j.enpol.2018.08.052.

Saaty, T.L., 1990, How to make a decision: The analytic hierarchy process: European Journal of Operational Research, v. 48, p. 9 26, doi:10.1016/0377-2217(90)90057-I.

Saaty, T.L., 2007, Time dependent decision-making; dynamic priorities in the AHP/ANP: Generalizing from points to functions and from real to complex variables: Mathematical and Computer Modelling, v. 46, p. 860-891, doi:10.1016/j.mcm.2007.03.028.

Sabo, M.L., Mariun, N., Hizam, H., Mohd Radzi, M.A., and Zakaria, A., 2016, Spatial energy predictions from large-scale photovoltaic power plants located in optimal sites and connected to a smart grid in Peninsular Malaysia: Renewable and Sustainable Energy Reviews, v. 66, p. 79-94, doi:10.1016/j.rser.2016.07.045.

Sadeghi, M., and Karimi, M., 2017, GIS-based solar and wind turbine site selection using multi-criteria analysis: Case study Tehran, Iran: International Archives of the Photogrammetry, Remote Sensing and Spatial Information Sciences - ISPRS Archives, v. 42, p. 469-476, doi:10.5194/isprs-archives-XLII-4-W4-4692017.

Sánchez-Lozano, J.M., García-Cascales, M.S., and Lamata, M.T., 2016, GIS-based onshore wind farm site selection using Fuzzy MultiCriteria Decision Making methods. Evaluating the case of Southeastern Spain: Applied Energy, v. 171, p. 86-102, doi:10.1016/j.apenergy.2016.03.030

Santika, W.G., Anisuzzaman, M., Bahri, P.A., Sha, G.M., Rupf, G. V, and Urmee, T., 2019, Energy Research \& Social Science From goals to joules: A quantitative approach of interlinkages between energy and the Sustainable Development Goals: v. 50, p. 201-214, doi:10.1016/j.erss.2018.11.016.

Shao, H., and Chu, L., 2008, Resource evaluation of typical energy plants and possible functional zone planning in China: v. $32, \mathrm{p}$ 283-288, doi:10.1016/j.biombioe.2007.10.001

Shaw, K., Shankar, R., Yadav, S.S., and Thakur, L.S., 2012, Supplier selection using fuzzy AHP and fuzzy multi-objective linear programming for developing low carbon supply chain: Expert Systems with Applications, v. 39, p. 8182-8192, doi:10.1016/j.eswa.2012.01.149.

Sobrino, J.A., Jiménez-Muñoz, J.C., and Paolini, L., 2004, Land surface temperature retrieval from LANDSAT TM 5: Remote Sensing of Environment, v. 90, p. $434-440$, doi:10.1016/j.rse.2004.02.003.

Sobrino, J.A., and Raissouni, N., 2000, Toward remote sensing methods for land cover dynamic monitoring: Application to Morocco:
International Journal of Remote Sensing, v. 21, p. 353-366, doi:10.1080/014311600210876.

Steinberger, J.K., and Roberts, J.T., 2010, From constraint to suf fi ciency : The decoupling of energy and carbon from human needs , 1975 - 2005: Ecological Economics, v. 70, p. 425-433, doi:10.1016/j.ecolecon.2010.09.014.

Sun, Y. wei, Hof, A., Wang, R., Liu, J., Lin, Y. jie, and Yang, D. wei, 2013, GIS-based approach for potential analysis of solar PV generation at the regional scale: A case study of Fujian Province:

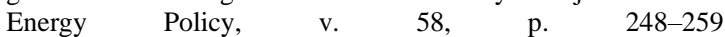
doi:10.1016/j.enpol.2013.03.002.

Tahri, M., Hakdaoui, M., and Maanan, M., 2015, The evaluation of solar farm locations applying Geographic Information System and Multi-Criteria Decision-Making methods: Case study in southern Morocco: Renewable and Sustainable Energy Reviews, v. 51, p. 1354-1362, doi:10.1016/j.rser.2015.07.054.

Tian, J., and Yan, Z.F., 2013, Fuzzy analytic hierarchy process for risk assessment to generalassembling of satellite: Journal of Applied Research and Technology, v. 11, p. 568-577, doi:10.1016/S1665-6423(13)71564-5.

Touili, S., Alami, A., Azouzoute, A., El, Y., and Amrani, A., 2018 , ScienceDirect A technical and economical assessment of hydrogen production potential from solar energy in Morocco: International Journal of Hydrogen Energy, doi:10.1016/j.ijhydene.2018.10.136.

Tsikalakis, A. et al., 2011, Review of best practices of solar electricity resources applications in selected Middle East and North Africa (MENA) countries: Renewable and Sustainable Energy Reviews, v. 15, p. 2838-2849, doi:10.1016/j.rser.2011.03.005.

USGS, https://earthexplorer.usgs.gov/ (accessed June 2019).

Uyan, M., 2013, GIS-based solar farms site selection using analytic hierarchy process ( AHP ) in Karapinar region, Konya / Turkey: Renewable and Sustainable Energy Reviews, v. 28, p. 11-17, doi:10.1016/j.rser.2013.07.042.

Valor, E., and Caselles, V., 1996, Response of land cover types to land surface temperature derived from Landsat-5 TM in Nanjing Metropolitan Region, China: Environmental Earth Sciences, v. 75, p. 167-184, doi:10.1007/s12665-016-6202-4.

Watson, J.J.W., and Hudson, M.D., 2015, Regional Scale wind farm and solar farm suitability assessment using GIS-assisted multicriteria evaluation: Landscape and Urban Planning, v. 138, p. 20-31, doi:10.1016/j.landurbplan.2015.02.001.

World Bank, https://www.indexmundi.com/map/?v=81000 (accessed July 2019).

Yang, Q., Huang, T., Wang, S., Li, J., Dai, S., Wright, S., Wang, Y., and Peng, H., 2019, A GIS-based high spatial resolution assessment of large-scale PV generation potential in China: Applied Energy, v. 247, p. 254-269, doi:10.1016/j.apenergy.2019.04.005.

Zadeh, L.A., 1965, Fuzzy Sets-Information and Control-1965 Information and Control,

Zhang, J., Wang, Y., and Li, Y., 2006, A C++ program for retrieving land surface temperature from the data of Landsat TM/ETM+ band6: Computers and Geosciences, v. 32, p. 1796-1805, doi:10.1016/j.cageo.2006.05.001.

Zoghi, M., Houshang Ehsani, A., Sadat, M., javad Amiri, M., and Karimi, S., 2017, Optimization solar site selection by fuzzy logic model and weighted linear combination method in arid and semi-arid region: A case study Isfahan-IRAN: Renewable and Sustainable Energy Reviews, v. 68, p. 986-996, doi:10.1016/j.rser.2015.07.014. 